\title{
Use of an Active Canopy Sensor and SPAD Chlorophyll Meter to Quantify Geranium Nitrogen Status
}

\author{
Yun-wen Wang \\ Department of Grassland Science, College of Animal Science and Technology, \\ China Agricultural University, Beijing 100193, The People's Republic of \\ China
}

\author{
Bruce L. Dunn ${ }^{1}$ \\ Department of Horticulture and Landscape Architecture, Oklahoma State \\ University, $358 \mathrm{Ag}$ Hall, Stillwater, OK 74078-6027
}

\author{
Daryl B. Arnall \\ Department of Plant and Soil Sciences, Oklahoma State University, Stillwater, \\ OK 74078-6028

\section{Pei-sheng Mao China Agricultural University, Beijing 100193, The People's Republic of China} \\ Department of Grassland Science, College of Animal Science and Technology,
}

Additional index words. Pelargonium $\times$ hortorum, sensor technology, nutrition, plant quality, GreenSeeker ${ }^{\mathrm{TM}}$ pocket sensor, NDVI

\begin{abstract}
This research was conducted to investigate the potentials of normalized difference vegetation index (NDVI), a Soil-Plant Analyses Development (SPAD) chlorophyll meter, and leaf nitrogen $(\mathrm{N})$ concentration [\% dry matter (DM)] for rapid determination of $\mathbf{N}$ status in potted geraniums (Pelargonium $\times$ hortorum). Two $\mathrm{F}_{1}$ cultivars were chosen to represent a dark-green leaf cultivar, Horizon Deep Red, and a light-green leaf cultivar, Horizon Tangerine, and were grown in a soilless culture system. All standard 6-inch $(15.24-\mathrm{cm})$ pots filled with a medium received an initial topdress application of $5 \mathrm{~g}$ controlled-release fertilizer $(15 \mathrm{~N}-9 \mathrm{P}-12 \mathrm{~K})$, then plants were supplemented with additional $N$ in the form of urea at $0,50,100$, or $200 \mathrm{mg} \cdot \mathrm{L}^{-1} \mathrm{~N}$ every few days to produce plants ranging from $\mathrm{N}$-deficient to $\mathrm{N}$-sufficient. The NDVI readings of individual plants from a NDVI pocket sensor developed by Oklahoma State University were collected weekly until the flowering stage. Data on flower traits, including number of pedicels (NOP), number of full umbels per pot (NOFU), total number of flowers per pot (TNF), number of flowers per pedicel (NOF), and inflorescences diameter (IFD), were collected 3 months after initial fertilizer treatment. After measuring flower traits, pedicels were removed from each pot, and SPAD value, NDVI, and leaf $N$ concentration (g. $\left.\mathrm{kg}^{-1} \mathrm{DM}\right)$ were measured simultaneously. Cultivar and $\mathrm{N}$ rate significantly affected all but two flower and one $\mathrm{N}$ status parameters studied. The coefficient of determination $\boldsymbol{R}^{2}$ showed that NOP, NOFU, and TNF traits were more related to the $N$ rates and the status parameters studied for 'Horizon Tangerine' than for 'Horizon Deep Red'. For the latter cultivar, NOP and TNF traits were highly related to NDVI and SPAD values than N rates and leaf $\mathrm{N}$ content parameters. Correlation analysis indicated that the NDVI readings $\left(R^{2}=0.848\right.$ and 0.917$)$ and SPAD values $\left(R^{2}=0.861\right.$ and 0.950$)$ were significantly related to leaf $\mathrm{N}$ content $\left(\mathrm{g} \cdot \mathrm{kg}^{-1} \mathrm{DM}\right)$ between cultivars. However, sensitivity of the NDVI and chlorophyll values to $\mathrm{N}$ application rate in geranium was slightly less than leaf $\mathrm{N}$ content. Strong correlations $\left(R^{2}=0.974\right.$ and 0.979 , respectively) between NDVI and SPAD values were found within cultivars. The results demonstrated NDVI and SPAD values can be used to estimate $\mathbf{N}$ status in geranium. Because the pocket NDVI sensor will be cheaper than the SPAD unit, it has an advantage in determining $N$ content in potted ornamentals.
\end{abstract}

Geraniums (Pelargonium spp.) are an important crop for the U.S. bedding plant industry with a wholesale value of over $\$ 100$ million in 2010 for both seed and vegetatively produced plants (U.S. Department of Agriculture, 2010). Geraniums are typically grown under greenhouse conditions during the winter and spring seasons for the purpose of responding to the high demand of spring commercial plant roots, or be lost through runoff. Excessive $\mathrm{N}$ application leads to increased production costs and may cause contamination of ground and surface water sources as a result of runoff. Therefore, application of $\mathrm{N}$ fertilizer to plants should meet the needs of the crop for both economic and environmental reasons (Turner and Jund, 1994). For greenhouse container production, the $\mathrm{N}$ requirement not only varies with plant type and age, but also is limited by the small volume of growth medium held within the container.

Nitrogen fertilization requirements and plant tissue analysis standards for geraniums are available (Biamonte et al., 1993; Dole and Wilkins, 2005; Kofranek and Lunt, 1969; Krug et al., 2010; Mills and Jones, 1997; Price et al., 1997). However, the most common greenhouse irrigation practice is to apply an adequate fertilizer solution to cause some leaching that helps to prevent excess nutrients and soluble salt buildup. The volume of excess solution as a percentage of the total solution applied is termed the leaching fraction (LF) (Hershey and Paul, 1982). Theoretically, the optimum $\mathrm{N}$ fertilizer rate includes the LF in addition to the amount of $\mathrm{N}$ the plant requires. The recommended LF is 20\% (Mastalerz, 1977), but under drip irrigation, it may be in excess of $40 \%$ to $50 \%$. The exact time at which plants require fertilizer inputs is difficult to determine unless some method of monitoring is used (Altland et al., 2002). Three types of monitoring approaches, plant-based, soilbased, and reflectance-based non-destructive measurements, are commonly used to diagnose $\mathrm{N}$ deficiency, determine $\mathrm{N}$ requirements of crops, and improve N use efficiency (NUE). A visual approach is to monitor leaf color. However, by the time symptoms usually appear, plants have usually been deficient for at least a week. Electrical conductivity (EC) and $\mathrm{pH}$ values of the growth medium are generally used to monitor nutrition level and $\mathrm{N}$ leachate from the soil. Applying fertilizer based on these two values has been shown to be effective in reducing $\mathrm{N}$ leaching in geranium (Morvant et al., 2001), but it is time- and laborintensive to monitor single pots and also $\mathrm{N}$ estimation is not precise.

Because existing methods of soil and plant analysis can be unreliable and potentially timeconsuming, reflectance-based, non-destructive techniques have received increasing attention (Link and Reusch, 2006). Chlorophyll content of a plant, or greenness, is a useful index to assess the growth status and leaf $\mathrm{N}$ level of a plant (Seemann et al., 1987). For several horticultural crops, leaf $\mathrm{N}$ and chlorophyll concentration were found to be strongly correlated when checked using a SPAD chlorophyll meter (Neilsen et al., 1995; Shaahan et al., 1999; Vos and Bom, 1993; Wang et al., 2004; Westerveld et al., 2003; Zanin and Sambo, 2006). The SPAD meter has a peak chlorophyll absorbance at $650 \mathrm{~nm}$ and nonchlorophyll absorbance at $940 \mathrm{~nm}$ to calculate a value proportionate to the relative optical density based on the ratio between the two wavelengths (Minolta, 1989). In N-deficient plants, because of low chlorophyll content, the red reflectance 
is much higher, whereas the infrared region is much lower (Ajay et al., 1984). For some species, correlation between SPAD meter reading and leaf $\mathrm{N}$ concentration is low (Martín et al., 2007), and for broad leaf species, multiple measurements per leaf are required to acquire a representative SPAD value for a leaf greatly reducing the speed of acquisition (Chang and Robison, 2003).

Use of vegetative indices, calculated from optically sensed measurements, can also provide rapid, non-destructive readings that correlate with plant properties such as chlorophyll and plant nutrition (Raun et al., 1998). Use of vegetative indices from GreenSeeker ${ }^{\mathrm{TM}}$ (NTech Industries, Ukiah, CA) technology is widely accepted in large-scale agronomic field production of Zea mays L., Triticum aestivum L., and Gossypium hirsutum L. (Carrillo, 2006; Clay et al., 2006; Eitel et al., 2008) and has been investigated in turfgrass (Baghzouz et al., 2007; Bell et al., 2004; Xiong et al., 2007). Remote sensing using vegetative indices has been used for some horticultural crops including Helianthus annuus L., Brassica oleracea L., and Vitis L. (El-Shikha et al., 2007; Peñuelas et al., 1994) but is not practical for greenhouse settings. GreenSeeker ${ }^{\mathrm{TM}}$ technology is portable and uses an active lighting optical sensor with high-intensity light-emitting diodes that emit light at $660 \mathrm{~nm}$ (red) and $780 \mathrm{~nm}$ [near-infrared (NIR)] wavelengths. The magnitude of the light reflected from the target is measured by a photodiode detector. NDVI values are then generated from the reflectance values for red and NIR. Recently, a new handheld pocket NDVI sensor was developed at Oklahoma State University. It was developed to provide similar readings at a fraction of the cost as the original GreenSeeker ${ }^{\mathrm{TM}}$ technology and can be used to easily measure a single plant or multiple greenleafed plants in a greenhouse setting during the vegetative stage because colors will confound NDVI readings. The pocket NDVI unit is also projected to cost considerably less than a SPAD chlorophyll meter.

A close relationship between leaf greenness or chlorophyll content and a plant's $\mathrm{N}$ status has been reported in both agronomic as well as horticultural crops (Tremblay et al., 2011). Because of the correlation between $\mathrm{N}$ content and chlorophyll concentration, this research evaluated the feasibility of collecting indirect measurements of chlorophyll content. A new pocket optical NDVI sensor unit and the SPAD chlorophyll meter have not been

Received for publication 18 Aug. 2011. Accepted for publication 5 Nov. 2011.

We thank Sun Gro Horticulture for media donation. We are also grateful to Key Technologies R\&D Program of the $12^{\text {th }}$ Five-Year Plan (2011BAD17B01-02) funded by the Ministry of Science and Technology of China for supporting a visiting research stay of Yun-Wen Wang at Oklahoma State University. Approved for publication by the director, Oklahoma Agricultural Experiment Station.

${ }^{1}$ To whom reprint requests should be addressed; e-mail bruce.dunn@okstate.edu. studied for assessment of $\mathrm{N}$ status of potted geranium and their relationship with flower quality traits. The objective of this study was to see if NDVI and SPAD values could be used to monitor the nutrient status in potted geraniums.

\section{Materials and Methods}

Plant materials and growth conditions. On 2 Nov. 2010, seeds of two commercial geranium (Pelargonium $\times$ hortorum L.H. Bailey) $\mathrm{F}_{1}$ cultivars, Horizon Deep Red (dark-green leaves) and Horizon Tangerine (light-green leaves), were sown in 128-cell trays with Metro-Mix 702 potting mix (Sun Gro Horticulture, Bellevue, WA). On 15 Jan. 2011, uniform plants with six to eight leaves on average were selected and transferred into standard 6-inch $(15.24-\mathrm{cm})$ pots each with $0.35 \mathrm{~kg}$ of medium listed previously. A single plant was placed in each pot and plants were grown in the Department of Horticulture and Landscape Architecture research greenhouses in Stillwater, OK, under natural photoperiods. Air temperature was set at $18 / 21^{\circ} \mathrm{C}$ day/night $\left(65 / 70{ }^{\circ} \mathrm{F}\right)$ with a maximum photosynthetic photon flux density of $500 \mu \mathrm{mol} \cdot \mathrm{m}^{-2} \cdot \mathrm{s}^{-1}$ at $1200 \mathrm{HR}$. On 27 Jan., 2011, $5 \mathrm{~g}$ of $15 \mathrm{~N}-$ 9P-12 (Osmocote ${ }^{\circledR}$ Plus; The Scotts Co., Marysville, $\mathrm{OH}$ ) was applied on the surface of each pot. Plants were hand-watered with tap water at a rate of $\approx 250 \mathrm{~mL}$ per pot per irrigation event to avoid excessive leaching. For the first 7 weeks, plants were fertigated with a solution containing $0,50,100$, or 200 $\mathrm{mg} \cdot \mathrm{L}^{-1} \mathrm{~N}$ from fluid urea $(28 \%, 28 \mathrm{~N}-0 \mathrm{P}-0 \mathrm{~K})$ at every third irrigation, then plants were fertigated every other watering until flowering stage for a total of 19 irrigations with a fertilizer solution. Fertilizer solution was mixed in a plastic bucket and applied at the same volume as the water. Nitrogen treatments were designed to produce plants with $\mathrm{N}$ status ranging from deficient to excessive. The experiment, consisting of eight treatments (two cultivars $\times$ four $\mathrm{N}$ levels), was replicated 30 times with single-pot replications, thereby giving a total of 240 pots. Pots were arranged in a completely randomized design.

Normalized difference vegetation index, inflorescence, Soil-Plant Analyses Development value, and nitrogen content determination. Individual plants were scanned from all 240 pots for NDVI readings weekly (total of five rating dates) until the flowering stage using a NDVI pocket sensor (NTech Industries) developed by Oklahoma State University. During measurements, the sensor was placed 45 $\mathrm{cm}$ above the plant canopy, giving the sensor a circular field of view with a diameter of $11.85 \mathrm{~cm}$. To eliminate water status influence, all spectral readings were taken the day after plants were irrigated.

From 18 Apr. to 22 Apr., 2011, 3 months after initial $\mathrm{N}$ solution treatment and $35 \mathrm{~d}$ after initial pedicel appearance, data were collected for NOP, NOFU, TNF, NOF, and IFD by averaging two widths per umbel. Total number of flowers including opened and unopened flowers on each pedicel was randomly taken on 14 pots per $\mathrm{N}$ treatment.

After data collection for flower number and inflorescence size, all pedicels were removed from each pot. Plant canopy sensing was conducted using a SPAD chlorophyll meter (SPAD-502; Konica Minolta, Japan). For each pot, measurements were collected from four mature leaves from the middle to upper level of the plant. Additionally, because putting four pots together would generate a more flat and homogenous square area for the pocket sensor than an individual pot, every adjacent four pots of the same $\mathrm{N}$ treatment were gathered reducing replication by a factor of four, and NDVI measurements were taken from the center of where the pots were grouped on four points, which arranged near the corner point of scan area.

Immediately after scanning for NDVI, 15 mature leaves were collected from each pot in the four-pot group for a total of 60 leaves combined. Leaf samples were analyzed for total $\mathrm{N}$ content $\left(\mathrm{g} \cdot \mathrm{kg}^{-1} \mathrm{DM}\right)$ by the Soil, Water and Forage Analytical Laboratory at Oklahoma State University using a LECO TruSpec Carbon and Nitrogen Analyzer (LECO Corporation, St. Joseph, MI).

Data analysis. Collected data were analyzed using SAS software (SAS/Stat procedures, Release 9.02; SAS Institute, Inc., Cary, NC). Treatments were two geranium cultivars in a factorial combination with four $\mathrm{N}$ rates. Analysis of variance using the PROC GLM command in SAS was used to calculate the effects of $\mathrm{N}$ and cultivar on the parameters studied. For SPAD values, there were 30 replications and four observations per replication to serve as subsamples. Because measurements were taken on a four-pot group level, for NDVI, there were seven replications and four reading points per replication to serve as subsamples. For leaf $\mathrm{N}$ content $\left(\mathrm{g} \cdot \mathrm{kg}^{-1} \mathrm{DM}\right)$, there were seven replications without a subsample. For all flower parameters studied, there were seven replications and two subsamples. Means of main effects and interactions were separated by the protected least significant difference $(a=0.05$ and 0.01 ). In addition, correlation regression of the parameters with $\mathrm{N}$ rates for the linear, quadratic, and logarithmic functions were determined for each cultivar.

To prove the predictive ability of $\mathrm{N}$ rates and three $\mathrm{N}$ status parameters, the Pearson correlation coefficients $(r)$ and their $P$ values were tested within them and between flower quality traits using the PROC CORR procedure. All of the correlations were calculated over means of four $\mathrm{N}$ rates $(\mathrm{n}=4)$ for each cultivar. The coefficient of determination $R^{2}$ as squared correlation coefficient was used to indicate the explained variance (variance of the linear model's predictions) with the total variance of the data.

\section{Results}

Normalized difference vegetation index readings and effect of nitrogen supply. Along with plant size expansion, the NDVI values 
on a single geranium pot with various $\mathrm{N}$ application rates increased substantially from pre-treatment to $19 \mathrm{~d}$ after $\mathrm{N}$ treatment across both cultivars (Table 1). This indicated that before the plant canopy reached adequate coverage, the NDVI sensor may not accurately predict $\mathrm{N}$ needs because of underlying soil and other background reflectance. Another factor is that plants may already have adequate initial nutrition as seen with the significant $\mathrm{N}$ rates at pre-treatment. All $\mathrm{N}$ treatments reached a high value at $27 \mathrm{~d}$ after treatment (DAT) and decreased a little at 33 DAT before increasing again at $44 \mathrm{~d}$ after $\mathrm{N}$ treatment right before floral initiation (Table 1). Significantly different NDVI readings were found at each date between dark-leaf cultivar and light-leaf cultivar (Table 1). However, the difference of NDVI values was not significant within the four $\mathrm{N}$ rates at $27 \mathrm{DAT}$, but at all other sampling dates, NDVI values were significantly different among $\mathrm{N}$ rates (Table 1). After plant growth and expansion of plant size, the SES of NDVI decreased (Table 1).

Significant cultivar differences were seen for almost all of the flower parameters studied (NOP, NOFU, TNF, NOF, and IFD), except for NOP and IFD for inflorescence two. Nitrogen rate significantly affected all flower parameters (Tables 2 and 3). Under similar $\mathrm{N}$ rates, geranium (Pelargonium $\times$ hortorum) $\mathrm{F}_{1}$ 'Horizon Tangerine' showed fewer NOP, NOFU, and NOF $(P \leq 0.01)$ than 'Horizon Deep Red'. However, the two geranium cultivars responded similarly to variation of $\mathrm{N}$ level, as indicated by the non-significance of the two-factor interaction. Nitrogen rates increased among treatments getting additional $\mathrm{N}$ for NOP, NOF, and IFD (Tables 2 and 3) but also stimulated early flowering (data not shown). With increasing $\mathrm{N}$ rate, NOP and NOF increased quadratically and NOFU increased linearly (Table 2). Number of flowers and inflorescences size on each flower stem appeared similar; most increased quadratically with increasing $\mathrm{N}$ supply (Table 3 ). Plants receiving $100 \mathrm{mg} \cdot \mathrm{L}^{-1} \mathrm{~N}$ tended to have more flowers and bigger flower size than those receiving $50 \mathrm{mg} \cdot \mathrm{L}^{-1}$ and were not significantly greater than $200 \mathrm{mg} \cdot \mathrm{L}^{-1} \mathrm{~N}$, which indicates a $\mathrm{N}$ rate of $100 \mathrm{mg} \cdot \mathrm{L}^{-1}$ supplemented with $5 \mathrm{~g}$ of $15 \mathrm{~N}-9 \mathrm{P}-12 \mathrm{~K}$ (Osmocote ${ }^{\circledR}$ Plus) would supply sufficient available $\mathrm{N}$ at least under the initial six-flower-stem stage.

Effects of nitrogen supply on normalized difference vegetation index, Soil-Plant Analyses Development values, and leaf nitrogen content $\left(g \cdot \mathrm{kg}^{-1}\right.$ dry matter). The NDVI, SPAD value, and leaf $\mathrm{N}$ were measured simultaneously at the initial bloom stage. There were significant differences between cultivars $(P \leq$ $0.001)$ and $\mathrm{N}$ rates $(P \leq 0.001)$ for both NDVI and SPAD values. With increasing $\mathrm{N}$ rate, the cubic, quadratical, and linear trends of NDVI, SPAD, and leaf $\mathrm{N}$ content were significant (Table 4). Leaf $\mathrm{N}\left(\mathrm{g} \cdot \mathrm{kg}^{-1} \mathrm{DM}\right)$ only differed significantly within $\mathrm{N}$ rates $(P \leq 0.0001)$, and the difference was nonsignificant between the cultivars $(P>0.05)$ (Table 4$)$. There were no significant differences within interactions of cultivar and $\mathrm{N}$ rates, which indicated that the two geranium cultivars responded similarly to variation of $\mathrm{N}$ levels for NDVI, SPAD, and leaf $\mathrm{N}$ content values. Both NDVI and SPAD values were capable of differentiating the response of $\mathrm{N}$ across all $\mathrm{N}$ rates, but leaf $\mathrm{N}$ content did not show significant difference between $50 \mathrm{mg} \cdot \mathrm{L}^{-1}$ and $100 \mathrm{mg} \cdot \mathrm{L}^{-1}$ treatments. Leaf $\mathrm{N}$ content was capable of differentiating the response of $\mathrm{N}$ when comparing both 50 $\mathrm{mg} \cdot \mathrm{L}^{-1}$ and $100 \mathrm{mg} \cdot \mathrm{L}^{-1} \mathrm{~N}$ rates with the control $\left(0 \mathrm{mg} \cdot \mathrm{L}^{-1}\right)$ and high $\mathrm{N}$ rate $(200$ $\left.\mathrm{mg} \cdot \mathrm{L}^{-1}\right)$. The results indicated the sensitivity of the NDVI and the chlorophyll value to $\mathrm{N}$ supply in geranium. With increasing $\mathrm{N}$ rate, NDVI readings and leaf $\mathrm{N}$ content increased cubicly $(P \leq 0.001$ and $P \leq 0.01$, respectively), and SPAD values increased quadratically $(P \leq 0.0001)$ (Table 4$)$. Each of the Pearson linear correlation coefficients $(r)$ and their $P$ values $(\mathrm{N}$ rate vs. NDVI, $\mathrm{N}$ rate vs. $\mathrm{SPAD}, \mathrm{N}$ rate vs. leaf $\mathrm{N}$ content, NDVI vs. SPAD, NDVI vs. leaf $\mathrm{N}$ content, SPAD vs. leaf $\mathrm{N}$ content) were tested with data from both cultivars. For 'Horizon Deep Red', cor- relations between $\mathrm{N}$ rate vs. leaf $\mathrm{N}$ content and NDVI vs. SPAD were significant at the $P \leq$ 0.05 level. For 'Horizon Tangerine', correlations between NDVI vs. SPAD, NDVI vs. leaf $\mathrm{N}$ content, and SPAD vs. leaf $\mathrm{N}$ content were significant at the $P \leq 0.05$ level (Table 5). However, all three $\mathrm{N}$ status parameters nearly equally correlated with $\mathrm{N}$ supply rates with coefficients of determination $\left(R^{2}\right)$ ranging from 0.740 to 0.931 for 'Horizon Deep Red' and ranging from 0.759 to 0.900 for 'Horizon Tangerine'. For the two tested cultivars, the coefficients of determination $\left(R^{2}\right)$ in a linear relationship between the leaf $\mathrm{N}$ content and the sensor measurements, i.e., NDVI $\left(R^{2}=\right.$ 0.848 and 0.917 , respectively) and SPAD $\left(R^{2}=0.861\right.$ and 0.950 , respectively) were high enough to be used in practice. Given the high level of correlations, NDVI and SPAD value can be used to rapidly detect $\mathrm{N}$ status in geranium.

Relationship between flower traits with normalized difference vegetation index, SoilPlant Analyses Development value, and leaf nitrogen content $\left(g \cdot \mathrm{kg}^{-1}\right.$ dry matter). The aforementioned results indicated that $\mathrm{N}$ supply significantly increased for the NOP, the NOFU, and the TNF on an individual plant basis. Each of the Pearson linear correlation coefficients $(r)$ and their $P$ values (between $\mathrm{N}$ rate, plus three $\mathrm{N}$ status parameters, and three flower quality traits) were tested with data from both cultivars. For 'Horizon Deep Red', none of these correlations were significant at the $P \leq 0.05$ level; most of these relationships were not practical, because the coefficients of determination $\left(R^{2}\right)$ in the linear relationship were too low, except for the correlations between two flower quality traits (i.e., NOP and TNF) and the two sensors (i.e., NDVI and SPAD), which ranged from 0.705 between SPAD and TNF to 0.782 between NDVI and NOP (Table 6). However, most of these correlations were significant at the $P \leq 0.05$ level for 'Horizon Tangerine', and the lowest value of the coefficients of determination $\left(R^{2}\right)$ was 0.724 between $\mathrm{N}$ rate and TNF (Table $6)$. The results demonstrated the predictive

Table 1. Normalized difference vegetation index measurements on single geranium pot with different rates of nitrogen $(\mathrm{N})$ at one date of pre-treatment and four dates after treatment of fertilizer during the vegetative stage.

\begin{tabular}{|c|c|c|c|c|c|c|}
\hline Cultivar & $\begin{array}{c}\text { Nitrogen } \\
\text { rate }\left(\mathrm{mg} \cdot \mathrm{L}^{-1}\right)\end{array}$ & Pre-treatment & $19 \mathrm{DAT}^{\mathrm{z}}$ & 27 DAT NDVI & 33 DAT & $44 \mathrm{DAT}$ \\
\hline \multirow[t]{4}{*}{ Horizon Deep Red } & 0 & $0.492 \pm 0.0609$ & $0.702 \pm 0.0302$ & $0.740 \pm 0.0219$ & $0.726 \pm 0.0147$ & $0.721 \pm 0.0176$ \\
\hline & 50 & $0.475 \pm 0.0560$ & $0.681 \pm 0.0376$ & $0.742 \pm 0.0366$ & $0.737 \pm 0.0177$ & $0.751 \pm 0.0253$ \\
\hline & 100 & $0.497 \pm 0.0622$ & $0.706 \pm 0.0301$ & $0.750 \pm 0.0234$ & $0.737 \pm 0.0162$ & $0.759 \pm 0.0225$ \\
\hline & 200 & $0.471 \pm 0.0623$ & $0.686 \pm 0.0377$ & $0.739 \pm 0.0241$ & $0.732 \pm 0.0190$ & $0.761 \pm 0.0215$ \\
\hline \multirow[t]{4}{*}{ Horizon Tangerine } & 0 & $0.440 \pm 0.0646$ & $0.649 \pm 0.0584$ & $0.707 \pm 0.0440$ & $0.683 \pm 0.0227$ & $0.706 \pm 0.0124$ \\
\hline & 50 & $0.433 \pm 0.0661$ & $0.630 \pm 0.0690$ & $0.711 \pm 0.0256$ & $0.689 \pm 0.0247$ & $0.737 \pm 0.0100$ \\
\hline & 100 & $0.486 \pm 0.0733$ & $0.660 \pm 0.0553$ & $0.720 \pm 0.0540$ & $0.695 \pm 0.0219$ & $0.745 \pm 0.0161$ \\
\hline & 200 & $0.432 \pm 0.0805$ & $0.644 \pm 0.0639$ & $0.725 \pm 0.0319$ & $0.691 \pm 0.0200$ & $0.746 \pm 0.0163$ \\
\hline Cultivar & & $* * * * y$ & $* * * *$ & $* * * *$ & $* * * *$ & $* * * *$ \\
\hline $\mathrm{N}$ rates & & $* *$ & $*$ & NS & $*$ & $* * * *$ \\
\hline $\mathrm{CV} \times \mathrm{N}$ & & NS & NS & NS & NS & NS \\
\hline $\operatorname{LSD}_{0.05}{ }^{\mathrm{x}}$ & & 0.0335 & 0.0253 & 0.0175 & 0.0101 & 0.00929 \\
\hline$\underline{L S D}_{0.01}$ & & 0.0440 & 0.0332 & 0.0229 & 0.0132 & 0.0122 \\
\hline
\end{tabular}

${ }^{\mathrm{z}} \mathrm{DAT}=$ days after a pre-treatment of controlled-release fertilizer. The average means $(\mathrm{n}=30)$ and sEs are presented.

$\mathrm{y}_{\mathrm{NS}}, *, * *, * * *, * * *$ Nonsignificant or significant at $P \leq 0.05, P \leq 0.01, P \leq 0.001$, or $P \leq 0.0001$, respectively.

${ }^{\mathrm{x}} \mathrm{LSD}_{0.05}=$ Fisher's protected least significant difference at $P \leq 0.05$ and $P \leq 0.01$, respectively. 
abilities of NDVI, SPAD, and leaf N content for flower quality despite being complicated by various responses within flower traits to $\mathrm{N}$ rates and cultivar effects.

\section{Discussion}

For ornamental plants growing in a greenhouse, $\mathrm{N}$ requirement varies with plant age and type. Krug et al. (2010) proved that optimal nutrient ranges of potted geranium vary among cultivars as a result of leaf color and physiological age of the plant, and noted as plants matured, $\mathrm{N}$ concentration decreased. At both the young and mature stages of growth, the dark-colored leaved cultivar had higher concentrations of $\mathrm{N}$ compared with the lightcolored leaved cultivar (Krug et al., 2010). However, in the greenhouse industry, broader and general ranges from 150 to $300 \mathrm{mg} \cdot \mathrm{L}^{-1}$ on a continual basis are used for commercial fertilizer recommendations for geraniums (Biamonte et al., 1993; Hammer, 1991; Whipker, 1998), which do not account for physiological age and leaf color type.

Based on the low rate ( $8 \mathrm{~g}$ ) of suggested surface application for a 6-inch pot of Osmocote $\AA$ Plus, the initial level of $N$ was at a much lower level than recommended. Addition of $\mathrm{N}$ in the form of urea significantly increased number of pedicels, number of flowers, and inflorescence size (Table 2), indicating optimal $\mathrm{N}$ supply is important for overall growth and plant quality in potted geranium. Krug et al. (2010) using Excel (13$2-13$, which contains $13 \mathrm{~N}-0.86 \mathrm{P}-10.8 \mathrm{~K}$ ) liquid fertilizer found that sufficient ranges for $\mathrm{N}$ in geraniums decreased from 36.2 to 40.2 $\mathrm{g} \cdot \mathrm{kg}^{-1}(3.62 \%$ to $4.02 \%) \mathrm{DM}$ to 29.1 to 35.1 $\mathrm{g} \cdot \mathrm{kg}^{-1}(2.91 \%$ to $3.51 \%)$ DM with the lightcolored leaf cultivar and decreased from 39.9 to $41.5 \mathrm{~g} \cdot \mathrm{kg}^{-1}(3.99 \%$ to $4.15 \%) \mathrm{DM}$ to 32.4

Table 2. Effects of nitrogen $(\mathrm{N})$ rates on number of flowers and number of pedicels on two geranium cultivars.

\begin{tabular}{|c|c|c|c|c|}
\hline Cultivar & $\begin{array}{c}\text { Nitrogen } \\
\text { rate }\left(\mathrm{mg} \cdot \mathrm{L}^{-1}\right)\end{array}$ & $\begin{array}{c}\text { No. of } \\
\text { pedicels/plant }^{z}\end{array}$ & $\begin{array}{c}\text { No. of full } \\
\text { umbels/plant }\end{array}$ & $\begin{array}{c}\text { No. of } \\
\text { flowers/plant }\end{array}$ \\
\hline \multirow[t]{4}{*}{ Horizon Deep Red } & 0 & $5.7 \pm 0.8$ & $4.5 \pm 0.8$ & $343.5 \pm 63.3$ \\
\hline & 50 & $7.3 \pm 1.8$ & $4.5 \pm 1.3$ & $492.1 \pm 104.0$ \\
\hline & 100 & $8.6 \pm 1.4$ & $5.6 \pm 1.3$ & $564.7 \pm 52.5$ \\
\hline & 200 & $7.6 \pm 1.3$ & $5.0 \pm 0.9$ & $481.7 \pm 73.3$ \\
\hline \multirow[t]{4}{*}{ Horizon Tangerine } & 0 & $5.6 \pm 2.0$ & $3.6 \pm 1.4$ & $209.7 \pm 89.1$ \\
\hline & 50 & $6.6 \pm 1.8$ & $4.1 \pm 1.0$ & $294.2 \pm 67.1$ \\
\hline & 100 & $7.4 \pm 2.0$ & $4.6 \pm 1.6$ & $330.3 \pm 104.4$ \\
\hline & 200 & $7.6 \pm 2.5$ & $4.9 \pm 2.2$ & $338.6 \pm 100.0$ \\
\hline \multicolumn{2}{|l|}{ Cultivar } & $\mathrm{NS}^{\mathrm{y}}$ & $*$ & $* * *$ \\
\hline \multicolumn{2}{|l|}{$\mathrm{N}$ rates } & $* * *$ & $*$ & $* * *$ \\
\hline \multicolumn{2}{|l|}{$\mathrm{CV} \times \mathrm{N}$} & NS & NS & NS \\
\hline \multicolumn{2}{|l|}{$\operatorname{LSD}_{0.05}{ }^{\mathrm{x}}$} & 1.39 & 0.98 & 66.32 \\
\hline \multirow[t]{2}{*}{$\mathrm{LSD}_{0.01}$} & & 1.87 & 1.32 & 88.73 \\
\hline & & $\mathrm{L}^{* * *} \mathrm{Q} \mathrm{Q}^{* * \mathrm{w}}$ & $\mathrm{L}^{* *}$ & $\mathrm{~L}^{* * * *} \mathrm{Q} * * * *$ \\
\hline
\end{tabular}

zThe average means $(\mathrm{n}=30)$ and SEs are presented. Mean number of flowers were taken from six umbels. $\mathrm{y}_{\mathrm{NS}}, * *, * * *, * * *$ Nonsignificant or significant at $P \leq 0.05, P \leq 0.01$, or $P \leq 0.001$, respectively. ${ }^{\mathrm{x}} \mathrm{LS}_{0.05}=$ Fisher's protected least significant difference at $P \leq 0.05$ and $P \leq 0.01$, respectively.

w**, ***,****Linear (L), or quadratic (Q), or cubic (C) response at $P \leq 0.01, P \leq 0.001$, or $P \leq 0.0001$ level, respectively.

to $35.8 \mathrm{~g} \cdot \mathrm{kg}^{-1}(3.24 \%$ to $3.58 \%)$ DM with the dark-colored leaf cultivar. Within this range, plants would have a satisfactory plant size, dry weight, and growth index. Compared with our results, only the leaf content of $200 \mathrm{mg} \cdot \mathrm{L}^{-1}$ $\mathrm{N}$ application treatment is within this sufficiency range, and $\mathrm{N}$ rates of $50 \mathrm{mg} \cdot \mathrm{L}^{-1}$ and $100 \mathrm{mg} \cdot \mathrm{L}^{-1}$ would have shown deficiency if the experiment were extended longer.

In greenhouse production, potted geranium quality, related to size and inflorescence number, is important for sales and is heavily influenced by the nutrient management program. Therefore, a procedure that allows for rapid and accurate determination of $\mathrm{N}$ status in geranium can be useful to growers. Altland et al. (2002) reported SPAD values were poorly correlated or changed at different collection dates to foliar total $\mathrm{N}$ in annual vinca [Catharanthus roseus (L.) G. Don] and concluded SPAD readings were not suitable for predicting plant $\mathrm{N}$ status. Our results demonstrated that indirect chlorophyll content measurements such as SPAD value and NDVI reading have a high correlation with $\mathrm{N}$ application rate and leaf $\mathrm{N}$ concentration in geraniums. This difference may be attributed to watering schedule or environmental factors.

According to NTech Industries (2009), current wheat and corn GreenSeeker ${ }^{\mathrm{TM}}$ algorithms require at least $50 \%$ of the $60-\mathrm{cm}$ footprint of each sensor to be covered by vegetation to calculate NDVI. It means wheat at the five to six leaf stage has reached adequate coverage to ensure a reliable reading and corn should be V8 to V12. For potted geranium, the coverage of a single plant was limited at the initial growth stage. Also, irregular shape or an uneven leaf surface would impede collecting a reliable NDVI reading. However, when potted geranium start to fill a pot out, we can put four pots together and create a more flat and homogenous square area guaranteeing more accurate readings. As a result of soil properties, water supply, growth

Table 3. Effects of nitrogen $(\mathrm{N})$ rates on flower quality for two geranium cultivars Horizon Deep Red and Horizon Tangerine 13 weeks after transplanting.

\begin{tabular}{|c|c|c|c|c|c|c|c|c|c|c|c|}
\hline \multirow[b]{2}{*}{ Cultivar } & \multirow[b]{2}{*}{$\begin{array}{c}\mathrm{N} \text { rate } \\
\left(\mathrm{mg} \cdot \mathrm{L}^{-1}\right)\end{array}$} & \multicolumn{2}{|c|}{ Inflorescence $1^{z}$} & \multicolumn{2}{|c|}{ Inflorescence 2} & \multicolumn{2}{|c|}{ Inflorescence 3} & \multicolumn{2}{|c|}{ Inflorescence 4} & \multicolumn{2}{|c|}{ Inflorescence 5} \\
\hline & & $\begin{array}{l}\text { No. of } \\
\text { flowers }\end{array}$ & Diam & $\begin{array}{l}\text { No. of } \\
\text { flowers }\end{array}$ & Diam & $\begin{array}{l}\text { No. of } \\
\text { flowers }\end{array}$ & Diam & $\begin{array}{l}\text { No. of } \\
\text { flowers }\end{array}$ & Diam & $\begin{array}{l}\text { No. of } \\
\text { flowers }\end{array}$ & Diam \\
\hline Horizon Deep & 0 & $119.3 \pm 20.1$ & $10.4 \pm 1.3$ & $79.4 \pm 19.4$ & $8.7 \pm 0.5$ & $55.4 \pm 11.2$ & $7.9 \pm 0.5$ & $50.6 \pm 16.0$ & $7.3 \pm 1.1$ & $23.8 \pm 11.2$ & $2.2 \pm 3.1$ \\
\hline & 200 & $134.3 \pm 30.6$ & $11.1 \pm 1.1$ & $89.3 \pm 20.6$ & $10.6 \pm 0.7$ & $68.4 \pm 17.4$ & $9.1 \pm 1.0$ & $59.6 \pm 15.7$ & $8.5 \pm 0.8$ & $50.6 \pm 19.0$ & $5.4 \pm 3.6$ \\
\hline Horizon & 0 & $51.5 \pm 12.9$ & $9.2 \pm 0.7$ & $44.1 \pm 12.8$ & $8.3 \pm 2.8$ & $39.1 \pm 21.5$ & $5.8 \pm 3.9$ & $33.2 \pm 18.0$ & $4.8 \pm 3.9$ & $18.4 \pm 16.4$ & $1.5 \pm 3.2$ \\
\hline & 200 & $71.9 \pm 12.4$ & $11.0 \pm 0.6$ & $58.4 \pm 12.3$ & $9.7 \pm 0.9$ & $52.2 \pm 19.7$ & $8.1 \pm 2.8$ & $40.1 \pm 12.9$ & $6.1 \pm 4.1$ & $37.1 \pm 19.1$ & $3.6 \pm 4.5$ \\
\hline Cultivar & & $* * * y$ & $*$ & $* * *$ & NS & $* * *$ & $* *$ & $* * *$ & $* * *$ & $* * *$ & * \\
\hline $\mathrm{N}$ rates & & $* *$ & $* * *$ & $* * *$ & $* * *$ & $* * *$ & $* *$ & $* *$ & $*$ & $* * *$ & $*$ \\
\hline $\mathrm{CV} \times \mathrm{N}$ & & NS & NS & NS & NS & NS & NS & NS & NS & NS & NS \\
\hline $\operatorname{LSD}_{0.05}{ }^{\mathrm{x}}$ & & 16.05 & 0.86 & 11.48 & 0.91 & 12.37 & 1.62 & 13.73 & 2.21 & 14.33 & 3.02 \\
\hline $\mathrm{LSD}_{0.01}$ & & 21.48 & 1.14 & 15.36 & 1.22 & 16.56 & 2.16 & 18.37 & 2.95 & 19.18 & 4.05 \\
\hline
\end{tabular}

${ }^{\mathrm{z}}$ The average means $(\mathrm{n}=14)$ and sES are presented.

${ }^{y} \mathrm{NA}, \mathrm{NS}, *, * *, * *$ Not available, non-significant, or significant at $P \leq 0.05, P \leq 0.01$, or $P \leq 0.001$, respectively.

${ }^{\mathrm{LSD}_{0.05}}$ or $\mathrm{LSD}_{0.01}=$ Fisher's protected least significant difference at $P \leq 0.05$ and $P \leq 0.01$, respectively.

w*, $* *, * * *, * * * *$ Linear (L), or quadratic (Q), or cubic (C) response at $P \leq 0.05, P \leq 0.01, P \leq 0.001$, or $P \leq 0.0001$ level, respectively. 
Table 4. Effects of nitrogen $(\mathrm{N})$ rates on estimated chlorophyll and NDVI values for two geranium cultivars during the flowering stage with pedicels removed.

\begin{tabular}{|c|c|c|c|c|}
\hline Cultivar $^{z}$ & $\begin{array}{l}\text { Nitrogen rate } \\
\left(\mathrm{mg} \cdot \mathrm{L}^{-1}\right)\end{array}$ & $\mathrm{NDVI}^{\mathrm{y}}$ & SPAD & $\begin{array}{c}\text { Leaf N content } \\
\left(\mathrm{g} \cdot \mathrm{kg}^{-1} \mathrm{DM}\right)\end{array}$ \\
\hline \multirow[t]{4}{*}{ Horizon Deep Red } & 0 & $0.776 \pm 0.014$ & $44.8 \pm 8.1$ & $19.03 \pm 1.98$ \\
\hline & 50 & $0.828 \pm 0.013$ & $55.1 \pm 5.0$ & $26.89 \pm 3.40$ \\
\hline & 100 & $0.841 \pm 0.011$ & $61.0 \pm 5.3$ & $27.34 \pm 5.69$ \\
\hline & 200 & $0.852 \pm 0.010$ & $63.9 \pm 4.5$ & $35.56 \pm 1.36$ \\
\hline \multirow[t]{4}{*}{ Horizon Tangerine } & 0 & $0.761 \pm 0.021$ & $39.1 \pm 6.1$ & $20.11 \pm 2.03$ \\
\hline & 50 & $0.816 \pm 0.013$ & $49.2 \pm 4.7$ & $26.49 \pm 1.65$ \\
\hline & 100 & $0.835 \pm 0.012$ & $54.4 \pm 4.4$ & $27.23 \pm 4.16$ \\
\hline & 200 & $0.846 \pm 0.013$ & $58.6 \pm 4.8$ & $32.01 \pm 2.08$ \\
\hline \multicolumn{2}{|l|}{ Cultivar } & $* * * \mathrm{x}$ & $* * *$ & NS \\
\hline \multicolumn{2}{|l|}{$\mathrm{N}$ rates } & $* * *$ & $* * *$ & $* * * *$ \\
\hline \multicolumn{2}{|l|}{$\mathrm{CV} \times \mathrm{N}$} & NS & NS & NS \\
\hline \multicolumn{2}{|l|}{$\operatorname{LSD}_{0.05}{ }^{\mathrm{w}}$} & 0.0088 & 1.71 & 3.253 \\
\hline \multirow{2}{*}{\multicolumn{2}{|c|}{$\operatorname{LSD}_{0.01}$}} & 0.0118 & 2.25 & 4.353 \\
\hline & & $\mathrm{L} * * * * \mathrm{Q} * * * * \mathrm{C} * * * \mathrm{z}$ & $\mathrm{L}^{* * * *} \mathrm{Q} * * * *$ & $\mathrm{~L} * * * * \mathrm{C}^{* *}$ \\
\hline
\end{tabular}

z**, ***,****Linear (L), or quadratic (Q), or cubic $(\mathrm{C})$ response at $P \leq 0.01, P \leq 0.001$, or $P \leq 0.0001$ level, respectively.

${ }^{\mathrm{y}}$ The average means $(\mathrm{n}=7)$ except for $\operatorname{SPAD}(\mathrm{n}=30)$ and ses are presented.

${ }_{\mathrm{NS}}, *, * *, * * * * * *$ Nonsignificant, or significant at $P \leq 0.05, P \leq 0.01, P \leq 0.001$, and $P \leq 0.0001$, respectively.

${ }^{{ }^{2} \mathrm{LSD}_{0.05}}$ or $\mathrm{LSD}_{0.01}=$ Fisher's protected least significant difference at $P \leq 0.05$ and $P \leq 0.01$, respectively NDVI = normalized difference vegetation index; SPAD = Soil-Plant Analyses Development; DM = dry matter.

Table 5. Coefficients of determination $\left(R^{2}\right)$ matrix for measured sensor parameters and leaf nitrogen $(\mathrm{N})$ content of two geranium cultivars.

\begin{tabular}{lccc}
\hline & NDVI & SPAD & $\begin{array}{c}\text { Leaf N content } \\
\left(\mathrm{g} \cdot \mathrm{kg}^{-1} \mathrm{DM}\right)\end{array}$ \\
\hline N rate $\left(\mathrm{mg} \cdot \mathrm{L}^{-1}\right)$ & \multirow{3}{*}{0.740} & Horizon Deep Red & $0.931^{* z}$ \\
NDVI & & 0.827 & 0.848 \\
SPAD & & $0.974^{*}$ & 0.861 \\
& & Horizon Tangerine & \\
N rate $\left(\mathrm{mg} \cdot \mathrm{L}^{-1}\right)$ & 0.759 & 0.867 & 0.900 \\
NDVI & & $0.979^{*}$ & $0.917^{*}$ \\
SPAD & & $0.950^{*}$ \\
\hline
\end{tabular}

z*Representing Pearson's correlation coefficient $(r)$ significant at $P \leq 0.05$.

NDVI = normalized difference vegetation index; SPAD = Soil-Plant Analyses Development; DM = dry matter.

Table 6. Coefficients of determination $\left(R^{2}\right)$ between measured parameters and flower quality traits of two geranium cultivars.

\begin{tabular}{lccc}
\hline & No. of pedicels/plant & No. of full umbels/plant & No. of flowers/plant \\
\hline \multirow{2}{*}{ N rate $\left(\mathrm{mg} \cdot \mathrm{L}^{-1}\right)$} & 0.380 & Horizon Deep Red & 0.290 \\
NDVI & 0.782 & 0.273 & 0.755 \\
SPAD & 0.775 & 0.375 & 0.705 \\
Leaf N content $\left(\mathrm{g} \cdot \mathrm{kg}^{-1} \mathrm{DM}\right)$ & 0.419 & 0.476 & 0.370 \\
& & 0.167 & \\
$\mathrm{~N}$ rate $\left(\mathrm{mg} \cdot \mathrm{L}^{-1}\right)$ & 0.813 & Horizon Tangerine \\
NDVI & $0.969^{*}$ & $0.914^{* z}$ & 0.724 \\
SPAD & $0.984^{* *}$ & $0.923^{*}$ & $0.996^{* *}$ \\
Leaf N content $\left(\mathrm{g} \cdot \mathrm{kg}^{-1} \mathrm{DM}\right)$ & 0.881 & $0.979^{*}$ & $0.968^{*}$ \\
\hline
\end{tabular}

z*Representing Pearson's correlation coefficient $(r)$ significant at $P \leq 0.05$.

$\mathrm{NDVI}=$ normalized difference vegetation index; SPAD $=$ Soil-Plant Analyses Development; $\mathrm{DM}=$ dry matter.

stages, sampling procedures (Olfs et al., 2005; Peterson et al., 1993), cultivars (Debaeke et al., 2006; Samborski and Rozbicki, 2002), and seasonal effects (Hussain et al., 2000), there are wide variations in values of indirect leaf chlorophyll measurements, and standards for each species and cultivar may need to be established at each growing facility.
Both handheld sensors (SPAD meter and pocket NDVI unit) are capable of indicating the status of canopy variables related to $\mathrm{N}$ for these two geranium cultivars. These sensors would be of little use if this information cannot be translated into $\mathrm{N}$ fertilization recommendations. Further research is needed to calibrate sensor measurements with $\mathrm{N}$ fertilizer needs for various plant species, growing stage, and recovery efficiency as well as seeing if the pocket NDVI sensor has an advantage in determining $\mathrm{N}$ content in other potted ornamentals.

\section{Literature Cited}

Ajay, S., D.S. Kamat, P.K. Aggarwal, and S.K. Sinha. 1984. Proc. ICAR-ISRO seminar on crop growth condition and remote sensing, IARI, 22-23 June 1984. p. 231-239.

Altland, J.E., C.H. Gilliam, J.H. Edwards, G.J. Keever, D.C. Fare, and J.L. Sibley. 2002. Rapid determination of nitrogen status in annual vinca. J. Environ Hort. 20:189-194.

Baghzouz, M., D.A. Devitt, and R.L. Morris. 2007 Assessing canopy spectral reflectance of hybrid bermudagrass under various combinations of nitrogen and water treatments. Appl. Eng. Agr. 23:763-774.

Bar-Tal, A., L. Karni, J. Oserovitz, A. Hazan, M Itach, S. Gantz, A. Avidan, I. Posalski, N. Tratkovski, and R. Rosenberg. 2001. Nitrogen nutrition of greenhouse pepper. II. Effect of nitrogen concentration and $\mathrm{NO}_{3}: \mathrm{NH}_{4}$ ratio on growth, transpiration, and nutrient uptake. HortScience 36:1252-1259.

Bell, G.E., B.M. Howell, G.V. Johnson, W.R Raun, J.B. Solie, and M.L. Stone. 2004. Optical sensing of turfgrass chlorophyll content and tissue nitrogen. HortScience 39:1130-1132.

Biamonte, R.L., E.J. Holcomb, and J.W. White 1993. Fertilization, p. 39-54. In: White, J.W. (ed.). Geraniums IV. Ball Publishing, Batavia, IL.

Carrillo, T. 2006. Normalized difference vegetative index, arthropod density, water and nitrogen interactions in ACALA 1517-99 cotton, Gossypium hirsutum (L). PhD diss., New Mexico State University, Las Cruces, NM.

Chang, S.X. and D.J. Robison. 2003. Nondestructive and rapid estimation of hardwood foliar nitrogen status using the SPAD-502 chlorophyll meter. For. Ecol. Mgt. 181:331-338.

Clay, D.E., K. Kim, J. Chang, S.A. Clay, and K. Dalsted. 2006. Characterizing water and nitrogen stress in corn using remote sensing. Agron J. 98:579-587.

Debaeke, P., P. Rouet, and E. Justes. 2006. Relationship between the normalized SPAD index and the nitrogen nutrition index: Application to durum wheat. J. Plant Nutr. 29:75-92

Dole, J.M. and H.F. Wilkins. 2005. Floriculture: Principles and species. 2nd Ed. Prentice Hall, Upper Saddle River, NJ. p. 455.

Eitel, J., D.S. Long, P.E. Gessler, and E.R. Hunt 2008. Combined spectral index to improve ground-based estimates of nitrogen status in dryland wheat. Agron. J. 100:1694-1702.

El-Shikha, D.M., P. Waller, D. Hunsaker, T. Clarke, and E. Barnes. 2007. Ground-based remote sensing for assessing water and nitrogen status of broccoli. Agr. Water Mgt. 92:183193

Hammer, P.A. 1991. Nutrition, p. 18-22. In: Tayama, H.K. and T.J. Rolls (eds.). Tips on growing zonal geraniums. Ohio State Univ. Bulletin FP-765. OFA Services, Inc., Columbus, $\mathrm{OH}$

Hershey, D.R. and J.L. Paul. 1982. Leaching-losses of nitrogen from pot chrysanthemums with controlled-release or liquid fertilization. Sci Hort. 17:145-152.

Hussain, F., K.F. Bronson, S. Yadvinder, S. Bijay, and S. Peng. 2000. Use of chlorophyll meter sufficiency indices for nitrogen management of irrigated rice in Asia. Agron. J. 92:875-879. 
Kofranek, A.M. and O.R. Lunt. 1969. A study of critical nutrient levels in Pelagonium hortorum, cultivar 'Irene'. J. Amer. Soc. Hort. Sci. 94:204-207.

Krug, B.A., B.E. Whipker, I. McCall, and B. Cleveland. 2010. Geranium leaf tissue nutrient sufficiency ranges by chronological age. J. Plant Nutr. 33:339-350.

Link, A. and S. Reusch. 2006. Implementation of site-specific nitrogen application-Status and development of the YARA N-Sensor, p. 37-41. In: NJF Seminar 390, Precision technology in crop production implementation and benefits, 7-8 Nov. 2006, Lillehammer, Norway. Norsk Jernbaneforbund, Stockholm, Sweden.

Martín, I., N. Alonso, M.C. López, M. Prieto, C. Cadahía, and E. Eymar. 2007. Estimation of leaf, root, and sap nitrogen status using the SPAD-502 chlorophyll meter for ornamental shrubs. Commun. Soil Sci. Plant Anal. 38:17851803.

Mastalerz, J.W. 1977. The greenhouse environment: The effect of environmental factors on the growth and development of flower crops. Wiley, New York, NY. p. 474.

Mills, H.A. and J.B. Jones, Jr. 1997. Plant analysis handbook II: A practical sampling, preparation, analysis, and interpretation guide. Micro-Macro Publishing, Athens, GA. p. 194.

Minolta. 1989. SPAD-502 Owner's manual. Industrial meter division. Minolta Corp., Ramsey, NJ.

Morvant, J.K., J.M. Dole, and J.C. Cole. 2001. Fertilizer source and irrigation systems affect geranium growth and nitrogen retention. HortScience 36:1022-1026.

Neilsen, D., E.J. Hogue, L.C. Herbert, P. Parchomchuk, and G.H. Neilsen. 1995. Use of rapid techniques for estimating the $\mathrm{N}$ status of fertigated apple trees. Acta Hort. 283:211-218.

NTech Industries. 2009. NTech Industries: GreenSeeker frequently asked questions, chlorophyll sensors perform variable rate fertilizing of wheat and corn crops. NTech Industries, Ukiah, CA.
Olfs, H.W., K. Blankenau, F. Brentrup, J. Jasper, A. Link, and J. Lammel. 2005. Soil and plantbased nitrogen fertilizer recommendations in arable farming. J. Plant Nutr. Soil Sci. 168: 414-431.

Peñuelas, J., J.A. Gamon, A.L. Fredeen, J. Merino, and C.B. Field. 1994. Reflectance indices associated with physiological changes in nitrogenand water-limited sunflower leaves. Remote Sens. Environ. 48:135-146.

Peterson, T.A., T.M. Blackmer, D.D. Francis, and J.S. Schepers. 1993. Using a chlorophyll meter to improve $\mathrm{N}$ management. Nebguide G931171A. Cooperative Extension Service, University of Nebraska, Lincoln, NE.

Price, G.H., G.C. Cresswell, and K.A. Handreck. 1997. Ornamentals, p. 464-504. In: Reuter, D.J. and J.B. Robinson (eds.). Plant analysis: An interpretation manual. CSIRO, Collingwood, Australia.

Raun, W.R., G.V. Johnson, H. Sembiring, E.V. Lukina, J.M. LaRuffa, W.E. Thomason, S.B. Phillips, J.B. Solie, M.L. Stone, and R.W. Whitney. 1998. Indirect measures of plant nutrients. Commun. Soil Sci. Plant Anal. 29: 1571-1581.

Samborski, S. and J. Rozbicki. 2002. Use of nitrogen sufficiency index for calibration of a chlorophyll meter SPAD-502 readings in winter triticale, p. 709-710. Proc. VII Congress of the European Soc. for Agron., 15-18 July 2002, Cordoba, Spain.

Seemann, J.R., T.D. Sharkey, J. Wang, and C.B. Osmond. 1987. Environmental effects on photosynthesis, nitrogen-use efficiency, and metabolite pools in leaves of sun and shade plants. Plant Physiol. 84:796-802.

Shaahan, M.M., A.A. El-Sayed, and A.A.A. Abou El-Nour. 1999. Predicting nitrogen, magnesium, and iron nutritional status in some perennial crops using a portable chlorophyll meter. Sci. Hort. 82:339-348.

Tremblay, N., E. Fallon, and N. Ziadi. 2011. Sensing of crop nitrogen status: Opportunities, tools, limitations, and supporting information requirements. HortTechnology 21:274-281.

Turner, F.T. and M.F. Jund. 1994. Assessing the nitrogen requirements of rice crops with a chlorophyll meter. Aust. J. Exp. Agr. 34:10011005.

U.S. Department of Agriculture, 2010. Floriculture crops 2010 summary. Sp Cr 6-1 (11). p. 23-24.

Van Iersel, M.W., P.A. Thomas, R.B. Beverly, J.G. Latimer, and H.A. Mills. 1998a. Nutrition affects pre- and post-transplant growth of impatiens and petunia plugs. HortScience 33:10141018.

Van Iersel, M.W., R.B. Beverly, P.A. Thomas, J.G. Latimer, and H.A. Mills. 1998b. Fertilizer effect on growth of impatiens, petunia, salvia, and vinca plug seedlings. HortScience 33:678682.

Vos, J. and M. Bom. 1993. Hand-held chlorophyll meter: A promising tool to assess the nitrogen status of potato foliage. Potato Res. 36:301308.

Wang, Q., J. Chen, and Y. Li. 2004. Nondestructive and rapid estimation of leaf chlorophyll and nitrogen status of peace lily using a chlorophyll meter. J. Plant Nutr. 27:557-569.

Westerveld, S.M., A.W. McKeown, C.D. ScottDupree, and M.R. McDonald. 2003. Chlorophyll and nitrate meters as nitrogen monitoring tools for selected vegetables in Southern Ontario. Acta Hort. 627:259-266.

Whipker, B.E. 1998. Fertility management for geraniums. North Carolina State University Horticulture Information Leaflet 504. North Carolina State University, Raleigh, NC.

Xiong, X., G.E. Bell, J.B. Solie, M.W. Smith, and B. Martin. 2007. Bermudagrass seasonal responses to nitrogen fertilization and irrigation detected using optical sensor. Crop Sci. 47:16031610 .

Zanin, G. and P. Sambo. 2006. Using SPAD-meter in nitrogen fertilization of Rosa chinensis Jacq. var. mutabilis. HortScience 41:969970 . 